\title{
PHOSPHORUS AND BORON EFFECTS ON NODULATION AND YIELD OF SOYBEAN UNDER NON-SALINE AGRO-ECOSYSTEM OF PATUAKHALI
}

\author{
S. Shabnam², S. Ahmed' ${ }^{1}$, S. Mia ${ }^{1}$ \\ ${ }^{1}$ Professor, Department of Agronomy, ${ }^{2} \mathrm{MS}$ Student, Department of Agronomy \\ Patuakhali Science and Technology University \\ Corresponding E-mail: sultanpstu@yahoo.com
}

Received: 18 November, 2020, Accepted: 23 December, 2020)

Keywords: Soybean, nodule, phosphorus, boron, yield

\begin{abstract}
The field experiment was conducted at Agronomy Field of Patuakhali Science and Technology University, Patuakhali during the period from December 2019 to May 2020 to evaluate the effect of phosphorus $\left(\mathrm{P}_{0}=0 \mathrm{~kg} \mathrm{Pha}^{-1}, \mathrm{P}_{1}=30 \mathrm{~kg} \mathrm{Pha}^{-1}, \mathrm{P}_{2}=60 \mathrm{~kg} \mathrm{P} \mathrm{ha}^{-1}\right.$, $\left.\mathrm{P}_{3}=90 \mathrm{~kg} \mathrm{Pha}^{-1}\right)$ and boron $\left(\mathrm{B}_{0}=0 \mathrm{~kg} \mathrm{~B} \mathrm{ha}^{-1}, \mathrm{~B}_{1}=4 \mathrm{~kg} \mathrm{~B} \mathrm{ha}^{-1}, \mathrm{~B}_{2}=6 \mathrm{~kg} \mathrm{~B} \mathrm{ha}^{-1}\right)$ and their combinations on nodulation and yield attributes of soybean. Number of nodules plant ${ }^{-1}$, number of pods plant ${ }^{-1}$, number of seeds pod, 1000-seed weight, seed yield, stover yield, biological yield and harvest index increased significantly up to $60 \mathrm{~kg} \mathrm{P} \mathrm{ha}^{-1}$. On the other hand, number of nodules plant ${ }^{-1}$, number pods plants ${ }^{-1}$, number of seeds pod ${ }^{-1}, 1000$-seed weight, seed yield, stover yield, biological yield and harvest index of soybean were enhanced significantly up to $4 \mathrm{~kg} \mathrm{~B} \mathrm{ha}^{-1}$. The combination of $60 \mathrm{~kg} \mathrm{Pha}^{-1}$ and $4 \mathrm{~kg} \mathrm{~B} \mathrm{ha}^{-1}$ depicted the highest number of nodules $(177.8)$, plant height $(75.60 \mathrm{~cm})$, number of pods plant $^{-1}$ (92.72), number of seeds pod ${ }^{-1}(2.92)$, weight of 1000-seed (155.3 g) seed yield $\left(1.91 \mathrm{t} \mathrm{ha}^{-1}\right)$, stover yield $\left(2.98 \mathrm{t} \mathrm{ha}^{-1}\right)$, biological yield $\left(4.89 \mathrm{t} \mathrm{ha}^{-1}\right)$ and harvest index (39.06\%). Thus, the combined application of $60 \mathrm{~kg} \mathrm{P} \mathrm{ha}^{-1}$ and $4 \mathrm{~kg} \mathrm{~B} \mathrm{ha}^{-1}$ could be the optimum for getting maximum yield of soybean.
\end{abstract}

\section{Introduction}

Soybean is the world's leading economic oil seed crop. It has a great value as food, feed and fuel. It has a tremendous value in agriculture as a good source of high quality plant protein and vegetable oils and nitrogen fixing ability. Soybean seed contains about 40-45\% protein, 20-22\% oil, 22-26\% carbohydrate and a high amount of $\mathrm{Ca}, \mathrm{P}$ and vitamins $\mathrm{A}, \mathrm{B}, \mathrm{C}$ and $\mathrm{D}$. It is used as raw materials in various industries viz. burnish, paint, soap, medicine and poultry feed (Messina, 1997).

The primary functions of phosphorus in plants are to store and transfer energy that is produced through the photosynthetic process to be used for growth and reproduction. Phosphorus has a nutritional requirement of soybean for nodule development. It plays a key role in the energy metabolism of all plant cells, particularly in nitrogen fixation as an energy-requiring process (Vadez et al., 1999).

Boron is essential for all plant growth. It aids in the transfer of sugars and nutrients from leaves to reproductive organ and increases pollination and seed development. Soybean requires an equal supplier of available boron, especially during flowering and seed development. Boron has several role in the soybean plant aiding cell formation, cell wall and vascular tissue formation, node number and plant height, flower development, pollen viability and ultimately pod formation and seed set. As boron is vital to flower formation and seed production, a decrease in boron supply during reproduction stage can result in decreased yield. Boron deficiency results in interveinal chlorons of the plant foliage with 
brittle leaves in the youngest growth. A dead terminal growing point is one of the symptoms of boron deficiency in soybean.

The southern part covers about $20 \%$ of the country which is equivalent to $\sim 30 \%$ of the net cropped area. A large part of these cultivable lands remain fallow during Rabi season, after harvesting T. aman. Soybean as moderately salt tolerant crop could be grown economically in the coastal area of Patuakhali (SAIC, 2007). Many research works were done at home and abroad to specify the levels of phosphorus and boron application for ensuring maximum productivity of soybean. However, more researches are needed for prescribing the levels of both the nutrients in the coastal area of Bangladesh. The present study was therefore undertaken to determine the optimum level of phosphorus and boron as well as their combinations for the maximum growth and yield performance of soybean at the coastal area.

\section{Materials and Methods}

The field experiment was conducted at Agronomy Field Patuakhali Science and Technology University, Dumki, Patuakhali during the period December 2019 to May 2020. The pre-cropping soil of experimental field (0-15 cm depth) was determined as silty loam texture having $\mathrm{pH}-6.6$, organic matter $-1.10 \%$, total nitrogen $-0.23 \%, \mathrm{P}-13.9 \mathrm{ppm}$, exchangeable $\mathrm{K}-14.3$ meq $100 \mathrm{~g}$ soil- $1, \mathrm{~S}-18$ $\mathrm{ppm}$ and $\mathrm{B}-59 \mathrm{ppm}$. The experiment was laid out in a factorial randomized complete block design with 3 replications. The variety BARI soybean 6 was used as test crop. The unit plot size was $4 \mathrm{~m} \times 3$ $\mathrm{m}$, spacing $30 \mathrm{~cm} \times 10 \mathrm{~cm}$. The experiment consisted two factors with four different levels of phosphorus such as $\mathrm{P}_{0}: 0 \mathrm{~kg} \mathrm{P} h a^{-1}, \mathrm{P}_{1}: 30 \mathrm{~kg} \mathrm{P} \mathrm{ha}^{-1}, \mathrm{P}_{2}: 60 \mathrm{~kg} \mathrm{P} \mathrm{ha}^{-1}, \mathrm{P}_{3}: 90 \mathrm{~kg} \mathrm{P} \mathrm{ha}^{-1}$ and 3 levels of boron such as $\mathrm{B}_{0}: 0 \mathrm{~kg} \mathrm{~B} \mathrm{ha}^{-1}, \mathrm{~B}_{1}: 4 \mathrm{~kg} \quad \mathrm{~B} \mathrm{ha}^{-1}$ and $\mathrm{B}_{2}: 6 \mathrm{~kg} \mathrm{~B} \mathrm{ha}^{-1}$. Half of urea and entire amount of other fertilizers was applied as basal during final land preparation and remaining half of urea was applied as top dressed after 21 days and 55 days after sowing. The soil moisture was maintained around $60 \%$ field capacity by supplying irrigation water at different dates. Different intercultural operations and plant protection measures were taken as and when necessary to raise healthy crop. The seeds of soybean were sown of 20 December 2019. The total number of nodules plant ${ }^{-1}$ was counted on five plants in different growth stages seedling, pre-flowering and flowering stage (i.e., 30, 60 and 90 days after sowing) to evaluate the nodulation pattern (Mete, 2015). The counted nodule number ${ }^{-1}$ then averaged them to have the nodule number plant ${ }^{-1}$. Harvesting was done on 18 April 2020. Data were collected an individual plant basis and seed yield plant ${ }^{-1}(\mathrm{~g})$ was estimated after cleaning and proper drying. Yield of individual plot excluding the broader plants was recorded and then converted to t ha ${ }^{-1}$. Plant performance was recorded taking measurements on plant height, number of pods plant ${ }^{-1}$, number of seeds pod $^{-1}$, weight of 1000-seeds, seed yield, stover yield, biological yield and harvest index. The collected data on different parameters were analyzed using Analysis of variance technique with the help of MSTAT-C computer program and the mean difference were compared by least significant test (LSD) at 5\% level of significance.

\section{Results and Discussion}

\section{Plant height}

Application of different levels of phosphorus and boron increased significantly the height of plant (Table 1). There were significant variations among phosphorus, boron and their interactions. In case of phosphorus, the highest plant height $(71.13 \mathrm{~cm})$ was observed with $60 \mathrm{~kg} \mathrm{P} \mathrm{ha}^{-1}\left(\mathrm{P}_{2}\right)$ and the shortest $(65.45 \mathrm{~cm})$ in control $\left(\mathrm{P}_{0}\right)$. In case of boron, the highest plant height $(68.14 \mathrm{~cm})$ was recorded with $4 \mathrm{~kg}$ $\mathrm{B} \mathrm{ha}^{-1}\left(\mathrm{~B}_{1}\right)$ and the shortest $(65.86 \mathrm{~cm})$ in $\mathrm{B}_{0}$ (Table 2$)$. In case interaction effect of phosphorus and boron, the highest plant height $\left(75.60 \mathrm{~cm}\right.$ ) was found in $\mathrm{P}_{2} \mathrm{~B}_{1}$ (Table 3). Further increase in the levels of $\mathrm{P}$ and B, decreased plant height. Similar findings were also reported by Singh et al. (1989). 
Table 1. Effect of different levels phosphorus on plant height, number of nodules plant $^{-1}$ and yield attributes of soybean

\begin{tabular}{|c|c|c|c|c|c|c|c|c|c|}
\hline Phosphorus & $\begin{array}{c}\text { Plant } \\
\text { height } \\
(\mathbf{c m})\end{array}$ & $\begin{array}{c}\text { Number } \\
\text { of } \\
\text { nodules } \\
\text { plant }^{-1}\end{array}$ & $\begin{array}{l}\text { Number } \\
\text { of pods } \\
\text { plant }^{-1}\end{array}$ & $\begin{array}{c}\text { Number } \\
\text { of seeds } \\
\text { pods }^{-1}\end{array}$ & $\begin{array}{c}1000- \\
\text { seed } \\
\text { weight } \\
(\mathrm{g})\end{array}$ & $\begin{array}{c}\text { Seed } \\
\text { yield } \\
\left(\mathrm{t} \mathrm{ha}^{-1}\right)\end{array}$ & $\begin{array}{l}\text { Stover } \\
\text { yield } \\
\left(\mathrm{t} \mathrm{ha} \mathbf{~ h}^{-1}\right)\end{array}$ & $\begin{array}{c}\text { Biological } \\
\text { yield } \\
\left(\mathrm{t} \mathrm{ha}^{-1}\right)\end{array}$ & $\begin{array}{c}\text { Harvest } \\
\text { index } \\
(\%)\end{array}$ \\
\hline $\mathrm{P}_{0}$ & & $100.4 \mathrm{~d}$ & & & $140.8 \mathrm{c}$ & $1.26 \mathrm{~d}$ & & & $34.62 \mathrm{c}$ \\
\hline $\mathrm{P}_{1}$ & $65.98 \mathrm{~b}$ & $125.4 \mathrm{c}$ & $76.97 \mathrm{~b}$ & $2.54 \mathrm{ab}$ & $142.3 \mathrm{~b}$ & $1.38 \mathrm{c}$ & $2.64 \mathrm{~b}$ & $4.02 \mathrm{a}$ & $34.33 \mathrm{c}$ \\
\hline $\mathrm{P}_{2}$ & $71.13 \mathrm{a}$ & $154.8 \mathrm{a}$ & $88.42 \mathrm{a}$ & $2.57 \mathrm{a}$ & $150.4 \mathrm{a}$ & $1.66 \mathrm{a}$ & $2.78 \mathrm{a}$ & $4.44 \mathrm{a}$ & $37.39 \mathrm{a}$ \\
\hline $\mathrm{P}_{3}$ & $65.52 \mathrm{~b}$ & $136.9 \mathrm{~b}$ & $79.05 \mathrm{~b}$ & $2.515 \mathrm{~b}$ & $143.0 \mathrm{~b}$ & $1.47 \mathrm{~b}$ & $2.51 \mathrm{c}$ & $3.98 \mathrm{~b}$ & $36.93 \mathrm{~b}$ \\
\hline $\mathrm{CV}(\%)$ & 3.87 & 4.05 & 6.11 & 5.57 & 3.05 & 4.50 & 2.82 & 2.97 & 2.52 \\
\hline
\end{tabular}

Figure followed by same letter (s) are statistically similar as per LSD at $5 \%$

$\mathrm{P}_{0}: 0 \mathrm{~kg} \mathrm{Pha}^{-1}, \mathrm{P}_{1}: 30 \mathrm{~kg} \mathrm{Pha}^{-1}, \mathrm{P}_{2}: 60 \mathrm{~kg} \mathrm{P} \mathrm{ha}^{-1}, \mathrm{P}_{3}: 90 \mathrm{~kg} \mathrm{P} \mathrm{ha}^{-1}$

\section{Number of nodules plant ${ }^{-1}$}

The nodule number plant ${ }^{-1}$ of soybean were found to increase significantly with increasing levels of phosphorus and boron application. The maximum number of nodules (154.8) plant $^{-1}$ was recorded with $60 \mathrm{~kg} \mathrm{P} \mathrm{ha}^{-1}\left(\mathrm{P}_{2}\right)$ and the minimum (100.4) in control $\left(\mathrm{P}_{0}\right)$ (Table 1). The number of nodules plant ${ }^{-1}$ of soybean varied significantly also due to the different levels of boron application. Among the boron treatments, $6 \mathrm{~kg} \mathrm{~B} \mathrm{ha}^{-1}$ gave the maximum number of nodules (138.6) (Table 2).

Table 2. Effect of different levels of boron on plant height, number of nodules plant $^{-1}$ and yield attributes of soybean

\begin{tabular}{lccccccccc}
\hline Boron & $\begin{array}{c}\text { Plant } \\
\text { height } \\
(\mathbf{c m})\end{array}$ & $\begin{array}{c}\text { Number } \\
\text { of nodules }_{\text {plant }^{-\mathbf{1}}}\end{array}$ & $\begin{array}{c}\text { Number } \\
\text { of pods }_{\text {plant }^{-1}}\end{array}$ & $\begin{array}{c}\text { Number of } \\
\text { seeds } \\
\text { pods }^{-\mathbf{1}}\end{array}$ & $\begin{array}{c}\mathbf{1 0 0 0 -} \\
\text { seed } \\
\text { weight } \\
(\mathbf{g})\end{array}$ & $\begin{array}{c}\text { Seed } \\
\text { yield } \\
\left(\mathbf{t ~ h a}^{-\mathbf{1}}\right)\end{array}$ & $\begin{array}{c}\text { Stover } \\
\text { yield } \\
\left(\mathbf{t ~ h a}^{-\mathbf{1}}\right)\end{array}$ & $\begin{array}{c}\text { Biological } \\
\text { yield } \\
\left(\mathbf{t ~ h a}^{-\mathbf{1}}\right)\end{array}$ & $\begin{array}{c}\text { Harvest } \\
\text { index } \\
(\%)\end{array}$ \\
\hline $\mathrm{B}_{0}$ & $67.07 \mathrm{ab}$ & $113.1 \mathrm{c}$ & $79.74 \mathrm{a}$ & $2.42 \mathrm{~b}$ & $142.6 \mathrm{~b}$ & $1.29 \mathrm{c}$ & $2.37 \mathrm{c}$ & $3.66 \mathrm{c}$ & $35.25 \mathrm{~b}$ \\
$\mathrm{~B}_{1}$ & $68.14 \mathrm{a}$ & $136.5 \mathrm{~b}$ & 79.8 & $2.54 \mathrm{a}$ & $145.3 \mathrm{a}$ & $1.59 \mathrm{a}$ & $2.71 \mathrm{a}$ & $4.30 \mathrm{a}$ & $36.97 \mathrm{a}$ \\
$\mathrm{B}_{2}$ & $65.86 \mathrm{~b}$ & $138.6 \mathrm{a}$ & $76.99 \mathrm{~b}$ & $2.57 \mathrm{a}$ & $144.5 \mathrm{a}$ & $1.44 \mathrm{~b}$ & $2.65 \mathrm{~b}$ & $4.09 \mathrm{~b}$ & $35.21 \mathrm{~b}$ \\
\hline $\mathrm{CV}(\%)$ & 3.87 & 5.57 & 6.11 & 4.05 & 3.05 & 4.50 & 2.82 & 2.97 & 2.52 \\
\hline
\end{tabular}

Figure followed by same letter (s) are statistically similar as per LSD at $5 \%$

$\mathrm{B}_{0}: 0 \mathrm{~kg} \mathrm{~B} \mathrm{ha}{ }^{-1}, \mathrm{~B}_{1}: 4 \mathrm{~kg} \mathrm{~B} \mathrm{ha}{ }^{-1}, \mathrm{~B}_{2}: 6 \mathrm{~kg} \mathrm{~B} \mathrm{ha}^{-1}$

In case interaction, the maximum number of (177.8) nodules plant ${ }^{-1}$ were found when crop was fertilized with $60 \mathrm{~kg} \mathrm{P} \mathrm{ha}^{-1}$ and $4 \mathrm{~kg} \mathrm{~B} \mathrm{ha}^{-1}$ (Table 3). These results showed that application of both $\mathrm{P}$ and $\mathrm{B}$ fertilizer individually increased nodulation with more response to $\mathrm{P}$ than $\mathrm{B}$. In previous studies showed that both $\mathrm{P}$ and $\mathrm{B}$ have positive effect on nodulation and biological nitrogen fixation (Hawkesford et al., 2011). When, P and B applied together, this effect augmented further suggesting an additive or synergistic effects. Mia et al. (2013) reported that micronutrients specifically P and B has substantial role on nodulation and overall $\mathrm{N}$ fixation. Therefore, our results corroborate the previous studies.

\section{Number of pods plant ${ }^{-1}$}

The highest number of pods plant ${ }^{-1}$ (88.42) was recorded with application of $60 \mathrm{~kg} \mathrm{P} \mathrm{ha}^{-1}$ which was significantly different from other treatments (Table 1). The results are in agreement with the findings of Khanam et al. (2016) who reported that the number of pods plant $^{-1}$ increased with the increase of phosphorus rate up to a certain limit and then decreased. Different levels of boron fertilizers also 
significantly influenced the number of pods plant ${ }^{-1}$. The maximum number of pods plant ${ }^{-1}$ of soybean (79.8) was recorded from $4 \mathrm{~kg} \mathrm{~B} \mathrm{ha}^{-1}$ (Table 2). Combined effect of $\mathrm{P}$ and B fertilizers application had significant effect on pods plant ${ }^{-1}$ of soybean. The highest number of pods (92.72) were recorded from $60 \mathrm{~kg} \mathrm{P} \mathrm{ha}^{-1}$ and $4 \mathrm{~kg} \mathrm{~B} \mathrm{ha}^{-1}$ (Table 3). Positive influence of $\mathrm{P}$ and $\mathrm{B}$ application on number of pods plant $^{-1}$ was also reported by Sentimenla et al. (2012).

Table 3. Interaction effect of phosphorus and boron on plant height, number of nodules plant ${ }^{-1}$ and yield attributes of soybean

\begin{tabular}{|c|c|c|c|c|c|c|c|c|c|}
\hline Interaction & $\begin{array}{l}\text { Plant height } \\
\text { (cm) }\end{array}$ & $\begin{array}{c}\text { Number } \\
\text { of } \\
\text { nodules } \\
\text { plant }^{-1}\end{array}$ & $\begin{array}{l}\text { Number } \\
\text { of pods } \\
\text { plant }^{-1}\end{array}$ & $\begin{array}{c}\text { Number } \\
\text { of seeds } \\
\text { pods }^{-1}\end{array}$ & $\begin{array}{c}1000- \\
\text { seed } \\
\text { weight } \\
(\mathrm{g}) \\
\end{array}$ & $\begin{array}{c}\text { Seed } \\
\text { yield } \\
\left.\text { ha }^{-1}\right)\end{array}$ & $\begin{array}{c}\text { Strover } \\
\text { yield } \\
\left(\mathbf{t ~ h a}^{-1}\right)\end{array}$ & $\begin{array}{c}\text { Biological } \\
\text { yield } \\
\left(\mathrm{t} \mathrm{ha}^{-1}\right)\end{array}$ & $\begin{array}{c}\text { Harvest } \\
\text { index } \\
(\%)\end{array}$ \\
\hline $\mathrm{P}_{0} \mathrm{~B}_{0}$ & & $87.72 \mathrm{j}$ & & & $142.5 \mathrm{e}$ & $1.21 \mathrm{gh}$ & $2.23 \mathrm{f}$ & $3.44 \mathrm{f}$ & $35.17 \mathrm{e}$ \\
\hline $\mathrm{P}_{0} \mathrm{~B}_{1}$ & $63.55 \mathrm{~h}$ & $99.43 \mathrm{i}$ & $73.03 \mathrm{e}$ & $2.38 \mathrm{e}$ & $139.3 \mathrm{fg}$ & $1.28 \mathrm{f}$ & $2.45 \mathrm{e}$ & $3.73 \mathrm{e}$ & $34.32 \mathrm{f}$ \\
\hline $\mathrm{P}_{0} \mathrm{~B}_{2}$ & & $114.0 \mathrm{~h}$ & $68.95 \mathrm{f}$ & $2.54 \mathrm{~cd}$ & $140.5 \mathrm{f}$ & $1.28 \mathrm{f}$ & $2.46 \mathrm{e}$ & $3.74 \mathrm{e}$ & $34.22 \mathrm{f}$ \\
\hline $\mathrm{P}_{1} \mathrm{~B}_{0}$ & $64.18 \mathrm{gh}$ & $115.3 \mathrm{~h}$ & $76.30 \mathrm{~d}$ & $2.49 \mathrm{~d}$ & $146.0 \mathrm{~d}$ & $1.24 \mathrm{~g}$ & $2.48 \mathrm{e}$ & $3.71 \mathrm{e}$ & $33.42 \mathrm{~g}$ \\
\hline $\mathrm{P}_{1} \mathrm{~B}_{1}$ & $68.22 \mathrm{c}$ & $128.0 \mathrm{f}$ & $77.55 \mathrm{~d}$ & $2.37 \mathrm{e}$ & $138.3 \mathrm{~g}$ & $1.49 \mathrm{~d}$ & $2.71 \mathrm{bc}$ & $4.20 \mathrm{~cd}$ & $35.48 \mathrm{e}$ \\
\hline $\mathrm{P}_{1} \mathrm{~B}_{2}$ & $65.55 \mathrm{ef}$ & $133.0 \mathrm{~d}$ & $77.07 \mathrm{~d}$ & $2.74 \mathrm{~b}$ & $142.5 \mathrm{e}$ & $1.42 \mathrm{e}$ & $2.73 \mathrm{~b}$ & $4.15 \mathrm{~d}$ & $34.22 \mathrm{f}$ \\
\hline $\mathrm{P}_{2} \mathrm{~B}_{0}$ & $70.70 \mathrm{~b}$ & $118.8 \mathrm{~g}$ & $87.28 \mathrm{~b}$ & $2.39 \mathrm{e}$ & $145.5 \mathrm{~d}$ & $1.53 \mathrm{c}$ & $2.63 \mathrm{~d}$ & $4.16 \mathrm{~d}$ & $36.78 \mathrm{c}$ \\
\hline $\mathrm{P}_{2} \mathrm{~B}_{1}$ & $75.60 \mathrm{a}$ & $177.8 \mathrm{a}$ & $92.72 \mathrm{a}$ & $2.92 \mathrm{a}$ & $155.3 \mathrm{a}$ & $1.91 \mathrm{a}$ & $2.98 \mathrm{a}$ & $4.89 \mathrm{a}$ & $39.06 \mathrm{a}$ \\
\hline $\mathrm{P}_{2} \mathrm{~B}_{2}$ & $67.10 \mathrm{~d}$ & $168.0 \mathrm{~b}$ & $85.25 \mathrm{c}$ & $2.41 \mathrm{e}$ & $150.5 \mathrm{~b}$ & $1.53 \mathrm{c}$ & $2.73 \mathrm{~b}$ & $4.25 \mathrm{c}$ & $36.00 \mathrm{~d}$ \\
\hline $\mathrm{P}_{3} \mathrm{~B}_{0}$ & & & & $2.4 \mathrm{e}$ & $136.3 \mathrm{~h}$ & $1.20 \mathrm{~h}$ & & & 37.05.bc \\
\hline $\mathrm{P}_{3} \mathrm{~B}_{1}$ & $65.18 \mathrm{fg}$ & $140.8 \mathrm{c}$ & $73.03 \mathrm{e}$ & $2.48 \mathrm{~d}$ & $148.3 \mathrm{c}$ & $1.68 \mathrm{~b}$ & $2.72 \mathrm{bc}$ & $4.40 \mathrm{~b}$ & $38.18 \mathrm{~b}$ \\
\hline $\mathrm{P}_{3} \mathrm{~B}_{2}$ & $65.00 \mathrm{fg}$ & $139.3 \mathrm{c}$ & $76.68 \mathrm{~d}$ & $2.58 \mathrm{c}$ & $144.5 \mathrm{~d}$ & $1.53 \mathrm{c}$ & $2.69 \mathrm{c}$ & $4.22 \mathrm{c}$ & $36.26 \mathrm{~d}$ \\
\hline $\mathrm{CV}(\%)$ & 3.87 & 5.57 & 6.11 & 4.05 & 3.05 & 4.50 & 2.82 & 2.97 & 2.52 \\
\hline
\end{tabular}

Figure followed by same letter (s) are statistically similar as per LSD at 5\% level of significance

\section{Number of seeds $\operatorname{pod}^{-1}$}

Number of seeds pod $^{-1}$ of soybean showed significant variation due to different levels of phosphorus (Table 1). The highest number of seeds $\operatorname{pod}^{-1}$ (2.57) was obtained when $60 \mathrm{~kg} \mathrm{P} \mathrm{ha}^{-1}$ was applied and it was minimum (2.44) in untreated plots (Table 1). These results confirmed the findings of Khanam et al. (2016) who reported that the number of seeds pod $^{-1}$ increased with the increase of phosphorus rate up to a certain limit and then decreased. Different levels of boron fertilizer also significantly influenced the number of seeds $\operatorname{pod}^{-1}$ (Table 2). The maximum number of seeds $\operatorname{pod}^{-1}$ of soybean (2.57) was recorded from $4 \mathrm{~kg} \mathrm{~B} \mathrm{ha}{ }^{-1}$. In case of interaction effect of phosphorus and boron fertilizers, the maximum number of seeds pod ${ }^{-1}$ (2.92) was found from $60 \mathrm{~kg} \mathrm{P} \mathrm{ha}^{-1}$ and $4 \mathrm{~kg} \mathrm{~B} \mathrm{ha}^{-1}$ (Table 3).

\section{Weight of 1000- seeds}

Different levels of $\mathrm{P}$ had significant effect on 1000-seed weight of soybean (Table 1). The heaviest 1000 -seed (150.4 g) was recorded from $60 \mathrm{~kg} \mathrm{P} \mathrm{ha}^{-1}$. The result was in agreement with those of Devi et al. (2012) who observed a significant variation in 1000-seed weight due to boron levels. The application of $4 \mathrm{~kg} \mathrm{~B} \mathrm{ha}^{-1}$ resulted in maximum 1000-seed weight (145.3 g) (Table 2). Although, the seed weight has been a quite static yield parameter, the combination of $\mathrm{P}$ and $\mathrm{B}$ had significant effect on 1000-seed weight of soybean (Begum et al. 2015, Sentimenla et al. (2012)). This results that the soil in the experimental sites is largely deficient of $\mathrm{P}$ and $\mathrm{B}$.

\section{Seed yield}

The highest soybean yield $\left(1.66 \mathrm{tha}^{-1}\right)$ was produced when the crop was fertilized with $60 \mathrm{~kg} \mathrm{P} \mathrm{ha}^{-1}$ and the lowest $\left(1.26 \mathrm{t} \mathrm{ha}^{-1}\right)$ in control treatment (Table 1). The result was supported by the findings of 
Khanam et al. (2016). Seed yield of soybean varied significantly with different levels of B fertilizer application (Table 2). The maximum yield of soybean $\left(1.59 \mathrm{t} \mathrm{ha}^{-1}\right)$ was recorded from $4 \mathrm{~kg} \mathrm{~B} \mathrm{ha-1}$ and the lowest $\left(1.29 \mathrm{t} \mathrm{ha}^{-1}\right)$ from control treatment (Table 2). The results were in agreement with those of Sentimenla et al. (2012) who observed that application of $1.5 \mathrm{~kg} \mathrm{~B} \mathrm{ha}^{-1}$ increased soybean seed yield. They also reported that $\mathrm{B}$ is vital to flower formation and seed production. The highest seed yield (1.91 $\mathrm{tha}^{-1}$ ) was recorded with the combination of $60 \mathrm{~kg} \mathrm{P} \mathrm{ha}^{-1}$ and $4 \mathrm{~kg} \mathrm{~B} \mathrm{ha}^{-1}$ (Table 3). The increased yield in this treatment was occurred possibly due to higher number of pods plant ${ }^{-1}$ and seeds pod $^{-1}$ with a heavier individual seed weight.

\section{Stover yield}

Stover yield of soybean varied significantly with different levels of $\mathrm{P}$ and $\mathrm{B}$ application. The highest stover yield $\left(2.78 \mathrm{t} \mathrm{ha}^{-1}\right)$ was obtained when the crop was fertilized with $60 \mathrm{~kg} \mathrm{P} \mathrm{ha}^{-1}$ and the lowest $\left(2.38 \mathrm{t} \mathrm{ha}^{-1}\right)$ in control plot (Table 1). The maximum stover yield $\left(2.71 \mathrm{t} \mathrm{ha}^{-1}\right)$ was recorded from $4 \mathrm{~kg} \mathrm{~B}$ $\mathrm{ha}^{-1}$ (Table 2). Different levels of $\mathrm{P}$ and B fertilizers in combination affected significantly the stover yield of soybean. The highest stover yield $\left(2.98 \mathrm{tha}^{-1}\right)$ was harvested with the combined application of $\mathrm{P}$ and $\mathrm{B} @ 60 \mathrm{~kg}$ and $4 \mathrm{~kg} \mathrm{ha}^{-1}$ respectively (Table 3).

\section{Biological yield}

Biological yield of soybean showed significant variation due to different levels of phosphorus (Table 1). The maximum biological yield $\left(4.44 \mathrm{t} \mathrm{ha}^{-1}\right)$ was recorded from $60 \mathrm{~kg} \mathrm{P}^{-1}$ while, the maximum biological yield $\left(4.30 \mathrm{tha}^{-1}\right.$ ) was recorded in $4 \mathrm{~kg} \mathrm{~B} \mathrm{ha}^{-1}$ (Table 2). The highest biological yield (4.89 $\mathrm{t}$ $\mathrm{ha}^{-1}$ ) was recorded from the combination of $60 \mathrm{~kg} \mathrm{P} \mathrm{ha}^{-1}$ and $4 \mathrm{~kg} \mathrm{~B} \mathrm{ha}^{-1}$ (Table 3). Generally biological yield increased with the increasing doses of $\mathrm{P}$ and $\mathrm{B}$ fertilizer application along with other recommended applied fertilizer. Since $\mathrm{P}$ and $\mathrm{B}$ has significant positive impact on biological nitrogen fixation, the plant might have had harvested more $\mathrm{N}$ through biological nitrogen fixation. In addition, nutrients maintain stoichiometry in building cells and organs and therefore, application of a deficient nutrient (as $\mathrm{P}$ and $\mathrm{B}$ in our case) could have improved uptake and assimilation of other nutrients resulting a significant improvement of yield (Hawkesford et al., 2011; Khanam et al., 2016; Sentimenla et al., 2012).

\section{Harvest index}

Harvest index of soybean varied significantly with different levels of phosphorus and boron application. The maximum H1 (37.39\%) was recorded from $60 \mathrm{~kg} \mathrm{P} \mathrm{ha}^{-1}$ (Table 1). The result was consistent with the findings of Malik et al. (2006) who found that $\mathrm{H} 1$ varied significantly due to different levels of phosphorus. The maximum H1 of soybean (36.97\%) was recorded from $4 \mathrm{~kg} \mathrm{~B} \mathrm{ha}{ }^{-1}$ (Table 2). Combined effect of phosphorus and boron had also significant effect on harvest index of soybean. The highest (39.06\%) was recorded from the combination of $60 \mathrm{~kg} \mathrm{P}^{-1}$ and $4 \mathrm{~kg} \mathrm{~B} \mathrm{ha}{ }^{-1}$ (Table 3).

\section{Conclusion}

The present study revealed that the application of $\mathrm{P}$ and $\mathrm{B}$ fertilizers influenced nodule formation, yield attributes and seed yield of soybean. The application of $60 \mathrm{~kg} \mathrm{P} \mathrm{ha}^{-1}$ and $4 \mathrm{~kg} \mathrm{~B} \mathrm{ha}^{-1}$ could be the most suitable levels for maximum productivity of soybean under non-saline agro-ecosystem of Patuakhali.

\section{Acknowledgement}

The authors avail the opportunity to express their sincere thanks and heartfelt gratitude to Bangladesh University Grants Commission for financial support and cooperation for conducting field experiment 
and preparation of the thesis for awarding MS degree in Agronomy, Patuakhali Science and Technology University.

\section{References}

Begum, A., M.A. Islam, Q.M. Ahmed, M.A. Islam and M.M. Rahman. 2015. Efffect of nitrogen and phosphorus on the growth and yield performance of soybean. Res. Agric. Livest. Fish. 2(1): 35-42.

Devi, K.N., L.N.K. Singh, T.S. Devi, H.N. Devi, T.B. Singh, K.K. Singh and W.M. Singh. 2012. Response of soybean [Glycine $\max$ (L.) Merrill] to sources and levels of phosphorus. J. Agril. Sci. 4(6): 4453.

Hawkesford, M., W. Horst, T. Kichey, H. Lambers, and J. Schjoerring. 2011. Functions of Macronutrients. In: Marschner, P. (Ed.), Marschner's Mineral Nutrition of Higher Plants: Third Edition. Academic Press, London, UK, pp.191-248.

Khanam, M.S. Islam., M.H. Ali, I.F. Chowdhury and S.M. Masum. 2016. Performance of soybean under different levels of phosphorus and potassium. Bangladesh Agron. J. 19(1): 99-108.

Malik, M.A., M.A. Cheema, H.Z. Khan and M.A. Wahid. 2006. Growth and yield response of soybean (Glycine $\max$ L.) to seed inoculation and varying phosphorus levels. J. Agric. Res. 44(1): 47-53.

Messina, M. 1997. Soyfoods: Their role in disease prevention and treatment, In: Liu, K (ed.) Soybeans: Chemistry, Technology and Utilizations, Chapman and Hill, New York pp. 442-466.

Mete, F.Z., S. Mia, F.A. Dijkstra, M. Abuyusuf and A.S.M.I. Hossain. 2015. Synergistic effects of biochar and NPK fertilizer on soybean yield in an alkaline soil. Pedosphere, 25: 713-719.

Mia, S., J.W. Van Groenigen, T.F.J. Van de Voorde, N.J. Oram and T.M. Bezemer. 2014. Biochar application rate affects biological nitrogen fixation in red clover conditional on potassium availability. Agric. Ecosys. Environ. 191: 83-91.

SAIC. 2007. SAARC Agricultural Statistics of 2006-07. SAARC Agricultural Information Center, Farmgate, Dhaka-1215, Bangladesh. p.23.

Sentimenla, A., K. Singh and S. Singh. 2012. Response of soybean to phosphorus and boron fertilization in acidic upland soil of Nagaland. J. Indian Soc. Soil Sci. 60(2): 01-04.

Singh, B.P., B. Singh and B.N. Singh. 1989. Influence of phosphorus and boron on picking behaviour and quality of french bean (Phaseolus vulgaris) under limited irrigation, grown in Alfisols deficient in phosphorus and boron. Indian J. Agril. Sci. 59: 541-543.

Vadez, V., J.H. Lasso., D.P. Beck and J.J. Drevon. 1999. Variability of nitrogen fixation in common bean (Phaseolus vulgaris L.) under phosphorus deficiency in related to phosphorus use efficiency. Euphytica 106: 231-242. 